\title{
PERTANGGUNGAN JAWAB PIDANA PEJABAT ATAS TINDAKAN MAL-ADMINISTRASI DALAM PENERBITAN IZIN DI BIDANG LINGKUNGAN
}

\author{
Ahmad Basuki \\ Fakultas Hukum Universitas Wijaya Kusuma Surabaya \\ e-mail: ahmadbasuki_uwks@yahoo.co.id
}

\begin{abstract}
ABSTRAK
Kuatnya arus demokratisasi sangat berpengaruh terhadap tuntutan good governance dalam tata kelola pemerintahan. Salah satu segi positif dari tuntutan tersebut adalah dengan telah diadopsinya prinsip akuntabilitas dalam Undang-Undang Perlindungan dan Pengelolaan Lingkungan Hidup bagi pejabat atas tindakan mal-administratif dalam penerbitan izin di bidang lingkungan. Atas dasar prinsip ini warga masyarakat yang menjadi korban pencemaran dan/atau perusakan lingkungan dapat mempersoalkan legalitas perizinan dan sekaligus meminta pertanggungjawaban hukum (pidana) kepada pejabat atas kerugian yang dideritanya.

Kata Kunci: tindakan mal-administrasi, izin, dan pertanggungan jawab pidana.
\end{abstract}

\begin{abstract}
The democratic strengthen is very influencing to the demand of good governance in managing the government. One of the positive demand is it has been adopted the principle of accountability of the constitution of protection and management of environment for official functionary on the act of mal administration in establishing permit of environment field, Based on the principle community who become sacrifice of pollution of environment can appeal the legal permit and the responsibility of criminal case towards the official functionary of disadvantages they have got.
\end{abstract}

Keywords: the act of mal administration, permit and the responsibility of criminal case

\section{PENDAHULUAN}

Dua masalah sentral yang saat ini sedang menjadi pusat perhatian dunia internasional adalah masalahmasalah yang berhubungan erat dengan Pembangunan dan dampaknya terhadap kualitas lingkungan hidup (quality of life). Hal ini terlihat dari perkembangan kongres-kongres PBB mengenai The Prevention of Crime and The Treatment of Offenders yang sering menyoroti bentuk-bentuk dimensi kejahatan terhadap pembangunan (crime against development), kejahatan terhadap kesejahteraan social (crime against social welfare), dan kejahatan terhadap kualitas lingkungan hidup (crime against the quality of life). Ketiga bentuk kejahatan tersebut saling berhubungan erat, karena memang tidak dapat dilepaskan keterkaitan problem pembangunan dengan masalah kesejahteraan masyarakat dan masalah lingkungan hidup. Hubungan erat tersebut terlihat dalam salah satu Laporan Kongres PBB ke-7 pada bulan September 1985 di Milan Italia, yang menyatakan bahwa kejahatan lingkungan (ecological/environmental crime) bersifat: a. mengganggu kualitas lingkungan hidup (impinged on the quality of life), b. mengganggu kesejahteraan material seluruh masyarakat (impinged on the material well-being of entire societes); dan c. mempunyai pengaruh negatif terhadap usaha-usaha pembangunan bangsa (had a negative impact on the development effort of nations) (Muladi dan Barda Nawawi Arief, 2010:182).

Mengingat hakikat dan dimensi pengaruh negatif yang sangat luas dari kejahatan lingkungan hidup itu, maka wajarlah apabila berbagai upaya dilakukan untuk menanggulanginya, antara lain melalui upaya penegakan hukum pidana. Upaya penanggulangan masalah lingkungan hidup dengan hukum pidana sesuai dengan Hasil Kongres PBB ke-8 tahun 1990 di Havana, Cuba. Dalam Resolusi antara mengenai The Role of Criminal Law in The Protection of Nature and the Environment (Dokumen No. A/CONF.144/L.4 tanggal 3 September 1990) antara lain dinyatakan bahwa di samping tindakan-tindakan berdasarkan hukum administrasi dan pertanggungjawaban berdasarkan hukum perdata, juga perlu diambil tindakan-tindakan terhadap masalah lingkungan 
hidup berdasarkan hukum pidana. Oleh karena itu, negara-negara anggota PBB dihimbau untuk mengimplimentasikan secara efektif sistem hukum nasional, termasuk hukum pidana (Muladi dan Barda Nawawi Arief, 2010:182)

Sebagai bentuk respon positif terhadap himbauan Resolusi No. A/CONF.144/L.4 tanggal 3 September 1990 tersebut, maka berbagai langkah progressif telah dilakukan oleh Pemerintah RI, antara lain dengan mengganti Undang-Undang Nomor 23 Tahun 1997 tentang Pengelolaan Lingkungan Hidup (Lembaran Negara RI Tahun 1997, Nomor 68, Tambahan Lembaran Negara RI Nomor 3699), yang lazim disebut UUPLH dengan Undang-Undang Nomor 32 Tahun 2009 tentang Perlindungan dan Pengelolaan Lingkungan Hidup (Lembaran Negara RI Tahun 1009 Tahun 140, Tambahan Lembaran Negara RI Nomor 5059), selanjutnya disebut UUPPLH.

Salah satu asas pengelolaan lingkungan dalam UUPPLH yang sebelumnya tidak dianut dalam UUPLH, yaitu asas tata kelola pemerintahan yang baik (Lihat Pasal 2 UUPPLH). Menurut Penjelasan Pasal 2 huruf $m$, bahwa yang dimaksud asas tata kelola pemerintahan yang baik adalah bahwa perlindungan dan pengelolaan lingkungan hidup dijiwai oleh prinsip partsipasi, transparansi, akuntabilitas, efisiensi dan keadilan.

Sebagai perwujudan dari prinsip akuntabilitas dalam penyelenggaran kegiatan perlindungan dan pengelolaan lingkungan oleh pejabat administratif, maka UUPPLH mengkriminalisasikan perbuatan pejabat administratif yang melanggar norma dan prosedur perizinan di bidang lingkungan. Hal ini tampak dalam Pasal 111 dan 112.

Pemanfaatan sanksi pidana pada Pasal 111 dan Pasal 112 UUPPLH menyelenggarakan kegiatan pengelolaan lingkungan tersebut harus dipahami dalam konteks fungsi hukum pidana sebagai ultimum remidium, karena secara substansial isi norma yang mengatur tentang pengelolaan lingkungan mempunyai karakter administratif (Siti Sundari Rangkuti, 2000:5), khususnya yang menyangkut penggunaan wewenang pemerintah di bidang perizinan.

\section{PEMBAHASAN}

\section{Prosedur dan Persyaratan Penerbitan Izin di Bidang Lingkungan}

Izin merupakan salah satu instrumen yuridis yang digunakan dalam hukum administrasi. Pemerintah menggunakan izin sebagai sarana yuridis mengatur tingkah laku warga masyarakat, sebagaimana yang dikatakan Berge: "De vergunning is een van de meest gebruikte in het administratief recht. Het bestuurs hanteert de vergunning als een juridisch middel om de burgers te sturen" (Tatiek Sri Djatmiati, 2007:2).

Dilihat dari segi tujuan, Berge menjelaskan motivasi pemberian izin adalah: a. keinginan untuk mengarahkan (mengendalikan aktivitas-aktivitas tertentu, misalnya izin bangunan), b. mencegah bahaya bagi lingkungan (izin-izin lingkungan), c. keinginan untuk melindungi obyek-obyek tertentu (izin tebang, izin membongkar monumen-monumen), d. hendak membagi benda-benda yang jumlahnya sedikit (izin penghunian daerah padat penduduk), e. mengarahkan dengan menyeleksi aktivitas-aktivitas (izin berdasarkan Dranken Horecawet, yang mana pengurus harus memenuhi persyaratan tertentu) (Tatiek Sri Djatmiati, 2007:6).

Dalam kaitannya dengan tujuan perizinan, patut pula disimak pendapat Brian dan Khaterine Thomson yang menggambarkan adanya aktivitas tertentu yang harus mendapatkan pengawasan Pemerintah melalui izin (Tatiek Sri Djatmiati, 2007:7).

Berdasarkan beberapa konsep di atas menunjukkan bahwa izin merupakan norma pengatur atau norma pengendali agar masyarakat dalam melakukan suatu kegiatan seperti business maupun kegiatan-kegiatan yang lainnya haruslah sesuai dengan ketentuan hukum yang berlaku. Oleh karena itulah izin merupakan suatu preventieve instrumenten, yang tujuan utamanya adalah mencegah perilaku menyimpang dari masyarakat agar memenuhi ketentuan-ketentuan hukum yang berlaku.

Fenomena praktek penerbitan izin yang banyak menimbulkan keresahan dan keluhan masyarakat karena dampak penyelenggaraan izin usaha atau kegiatan yang telah dikeluarkan menimbulkan berbagai macam perusakan dan pencemaran lingkungan (Tatiek Sri Djatmiati, 2007:3), perlu mendapatkan perhatian dan evaluasi, menyangkut prosedur dan persyaratan penerbitannya. Munculnya predikat izin premateur dan negara izin (vergunningsland) (Siti Sundari Rangkuti, 2000:142) merupakan sindiran dan kritik atas praktek perizinan yang bervariasi, rumit dan sulit ditelusuri dikarenakan mengedepankan motivasi atau tujuan yang meningkatkan pendapatan (retribusi) daerah, dan tidak mengindahkan pemenuhan terhadap persyaratan yang telah ditentukan. Maka dalam rangka mereformasi sistem perizinan perlu diarahkan untuk menuju kepada sistem perizinan lingkungan yang terpadu (integrale milieuvergunning).

Pemanfaatan instrumen perizinan dalam perlindungan dan pengelolaan lingkungan tidak cukup sekedar dengan upaya penyederhanaan prosedur 
perizinan ke arah one stop service (Pola Pelayanan Satu Atap) bukan bermakna sekedar integrasi aktivitas dengan berbagai meja yang harus dilalui pemohon dengan berbagai kewenangan yang demikian banyak, melainkan dibutuhkan integrasi prosedur. Dalam integrasi prosedur, langkah yang ditempuh adalah mengurangi atau memangkas wewenang untuk menerbitkan izin-izin dan rekomendasi yang sangat beragam, sehingga hanya izin inti saja yang harus ditempuh. Tidak dipungkiri hal yang demikian akan menimbulkan resistensi dari berbagai unit terkait, tetapi hal itu secara bertahap harus dapat dihindari (Tatiek Sri Djatmiati, 2007:4).

Reformasi prosedur perizinan yang mengarah pada penyederhanaan birokrasi menjadi izin lingkungan yang terpadu (integrale milieuvergunning) juga harus diimbangi dengan pembinaan, pengawasan dan penindakan terhadap aparat atau pejabat perizinan, sebagai bentuk akuntabilitas terhadap kewenangan yang dimilikinya. Hal ini penting dalam rangka menjawab berbagai bentuk penyimpangan terhadap prosedur dan persyaratan penerbitan izin yang berimplikasi terhadap munculnya izin premature yang selama ini banyak terjadi.

UUPPLH mengatur tentang prosedur dan persyaratan izin lingkungan yang tertuang dalam Pasal 36-41 UUPPLH. Kemudian hal yang penting lagi untuk dikemukakan adalah menyangkut persyaratan izin usaha dan/atau kegiatan sebagaimana yang ditegaskan dalan Pasal 40 (1). Pemahaman secara $a$ contrario terhadap Pasal 40 ayat (1) tersebut, berarti Menteri, Gubernur, atau Bupati/Walikota tidak boleh menerbitkan izin usaha dan/atau kegiatan tanpa dilengkapi izin lingkungan.

\section{Mal-Administrasi Pejabat dalam Penerbitan Izin di Bidang Lingkungan}

Menurut Pasal 1 Angka 3 Undang-Undang No. 5 Tahun 1986, Pejabat Tata Usaha Negara (selanjutnya disebut pejabat) adalah seseorang yang berdasarkan peraturan perundang-undangan berwenang untuk mengambil keputusan di bidangnya dalam rangka melaksanakan salah satu kegiatan Tata Usaha Negara.

Selanjutnya, untuk mengontrol pelaksanaan wewenang pejabat yang telah diberikan oleh peraturan perundang-undangan tersebut, secara yuridis disediakan beberapa instrumen hukum untuk memeriksa dan mengadilinya, yaitu jalur Peradilan Tata Usaha Negara, apabila pokok perkaranya menyangkut pengujian keabsahan Keputusan Tata Usaha Negara selanjutnya disebut KTUN, dan jalur peradilan umum, apabila pokok perkaranya menyangkut di luar KTUN, baik yang bersifat perdata maupun pidana.

Salah satu aspek yang memungkinkan adanya pertanggungjawaban pidana pejabat (Philipus M. Hadjon, 2011:20) dalam melaksanakan tugas dan fungsinya mengandung unsur mal-administratif. Secara etimologis (Philipus M. Hadjon, 2011:1920), mal-administrtif berasal dari bahasa latin, $m a l$ berarti jelek, jahat, dan administrare artinya melayani. Dengan demikian mal-administratif mengandung arti pelayanan yang jelek atau buruk. Laporan tahunan 1997 Ombudsman Eropa menjelaskan, bahwa: maladministration occurs when a public body fail to act in accordance with the rule or principle which is binding upon it. Secara lebih konkrit E.I. Sykes et.al., dalam bukunya General Principles of Administratief Law, 1989 menjelaskan, bahwa ... maladministration, a term which has been described as including bias, neglect, delay, inattention, incompetence, inaptitude, perversity, turpitude and upbitrarines.

Sejalan dengan kedua pengertian mal-admistrasi tersebut di atas, Pasal 1 butir 3 Undang-Undang Nomor 37 Tahun 2008 menjelaskan bahwa, maladministrasi adalah perilaku atau perbuatan melanggar hukum, melampaui wewenang, menggunakan wewenang untuk tujuan lain dari yang menjadi tujuan wewenang tersebut, termasuk kelalaian atau pengabaian kewajiban hukum dalam penyelenggaraan pelayanan publik yang dilakukan oleh Penyelenggara Negara dan Pemerintahan yang menimbulkan kerugian materiil dan/atau immaterial bagi masyarakat dan orang perseorangan.

Selanjutnya untuk menentukan suatu tindakan aparat atau pejabat publik bersifat mal-administratif atau tidak, menurut Philipus M. Hadjon dapat diukur berdasarkan 3 (tiga) parameter, yaitu: a. peraturan perundang-undangan, $b$. asas-asas umum pemerintahan yang baik, atau c. code of good administrative behavior.

Dengan pengertian dasar tersebut, mal-administrasi dikaitkan dengan perilaku dalam pelayanan, khususnya yang dilakukan oleh pejabat publik. Dikaitkan dengan norma hukum administrasi, mal-administrasi termasuk kategori norma perilaku aparat dalam pelayanan publik. Dalam posisinya sebagai norma perilaku aparat, maka setiap tindakan mal-administrasi mengandung resiko atau konsekuensi terhadap pertanggungjawaban pribadi (faute de personale), yang bersifat administratif, perdata, maupun pidana.

Sesuai dengan pengertian, sifat, dan parameter mal-administrasi sebagaimana telah dikemukakan 
di atas, dapat disimpulkan adanya 4 (empat) macam tindakan mal-administrasi yang berimplikasi terhadap pertanggungan jawab pidana pejabat, yaitu: pertama, pelanggaran terhadap prosedur penerbitan izin lingkungan sebagaimana dimaksud Pasal 37 ayat (1) UUPPLH; kedua, pelanggaran terhadap prosedur penerbitan izin usaha dan/atau kegiatan, sebagaimana diatur Pasal 40 ayat (1); ketiga, pelanggaran yang berupa pengabaian atau kelalaian terhadap kewajiban hukum untuk melakukan pengawasan terhadap ketaatan penanggungjawab usaha dan/atau kegiatan terhadap persyaratan izin usaha dan/atau kegiatannya, sebagaimana dimaksud dalam Pasal 71 ayat (1); dan keempat, pelanggaran yang berupa pengabaian atau kelalaian terhadap kewajiban hukum untuk melakukan pengawasan terhadap ketaatan penanggungjawab usaha dan/atau kegiatan terhadap persyaratan izin lingkungannya, sebagaimana dimaksud dalam Pasal 72 ayat (1).

\section{Pertanggungan Jawab Pidana Pejabat}

Sebagaimana yang telah dikemukakan sebelumnya, bahwa tindakan mal-administrasi pejabat menimbulkan cacat yuridis, sehingga melahirkan implikasi terhadap berbagai pertanggungan jawab hukum terhadap pejabat yang bersangkutan, baik secara administrasi, perdata maupun pidana.

Hukum Pidana mensyaratkan adanya 3 (tiga) hal dalam rangka pertanggungan jawab pidana (criminal responsibility), yang secara konsepsional oleh Sauer disebut sebagai Trias dalam Hukum Pidana. Ketiga persoalan tersebut adalah: tindak pidana, pertanggungjawaban pidana dan pidana (Sudarto, 1990:86). Dalam istilah yang lain Barda Nawawi Arief menyebut sebagai 3 (tiga) persoalan dasar dalam hukum pidana, yaitu: konsep Perbuatan (P), konsep Orang (O), dan konsep Pidana (P), yang disingkat POP.

Sesuai dengan taksonomi yang dikemukakan Sauer dan Barda Nawawi Arief tersebut, sistematika pembahasan pertanggungan jawab pidana pejabat dalam kaitannya dengan mal-administrasi dalam penerbitan izin di bidang lingkungan akan dilakukan.

a. Klasifikasi dan Rumusan Tindak Pidana

Sebagaimana telah dikemukakan sebelumnya, bahwa terdapat 4 (empat) macam tindakan maladministrasi, mempunyai implikasi terhadap pertanggungan jawab pidana pejabat, yaitu:

1. Pelanggaran terhadap prosedur dan persyaratan penerbitan izin.

Jenis Pelanggaran ini dapat dibedakan menjadi 2 (dua) macam, yaitu: pertama, pelanggaran terhadap prosedur dan persyaratan penerbitan izin lingkungan. Ketentuan yang mengatur jenis pelanggaran ini adalah Pasal 111 ayat (1). Berdasarkan formulasi Pasal 111 ayat (1) tersebut dapat diidentifikasi adanya 2 (dua) unsur utama (bestand delen) dari tindak pidananya, yaitu: (1) menerbitkan izin lingkungan, dan (2) tanpa dilengkapi dengan AMDAL, atau UKL-UPL sebagaimana dimaksud dalam Pasal 37 ayat (1).

Selanjutnya, jenis pelanggaran kedua, yaitu pelanggaran terhadap prosedur dan persyaratan penerbitan izin usaha dan/atau kegiatan. Ketentuan yang mengatur jenis pelanggaran ini adalah Pasal 111 ayat (2). Berdasarkan formulasi Pasal 111 ayat (2) tersebut dapat dikemukakan adanya 2 (dua) unsur utama (bestand delen) dari tindak pidananya, yaitu: (1) menerbitkan izin usaha dan/atau kegiatan, dan (2) tanpa dilengkapi dengan Izin Lingkungan, sebagaimana dimaksud dalam Pasal 40 ayat (1).

Dilihat dari segi taksonomi perumusan delik, maka dapat dikatakan bahwa kedua jenis pelanggaran terhadap prosedur dan persyaratan dalam penerbitan izin di bidang lingkungan tersebut di atas tergolong dalam "delicten met formele omschrijving", yaitu rumusan tindak pidana yang menekankan pada dilarangnya suatu perbuatan (Wirjono Prodjodokoro, 1989:34-35), dan tindak pidananya disebut sebagai tindak pidana formil (formeel delicten), yaitu tindak pidana yang perumusannya dititikberatkan pada perbuatan yang dilarang. Tindakan pidana tersebut telah dianggap selesai dengan dilakukannya perbuatan (Sudarto, 1990:57).

Sebagai tindak pidana formil, pembuktian terhadap terjadinya tindak pidana sebagaimana dimaksud dalam Pasal 111 ayat (1) dan ayat (2) sangat sederhana, yaitu pertama, adanya bukti yang berupa KTUN tentang pemberian izin lingkungan atau izin usaha dan/atau kegiatan; dan kedua, tidak diketemukan adanya AMDAL atau UKL-UPL dalam proses penerbitan izin usaha, atau tidak diketemukan adanya Izin Lingkungan dalam proses penerbitan izin usaha dan/atau kegiatan.

2. Pelanggaran berupa pengabaian terhadap kewajiban hukum untuk melakukan pengawasan

Dalam hal ini dibedakan menjadi 2 (dua) macam pengawasan, yaitu: pertama, pengawasan atas ketaatan penanggungjawab usaha dan/atau kegiatan terhadap persyaratan izin lingkungannya. Larangan terhadap pengabaian terhadap pengawasan jenis ini diatur dalam Pasal 112 jo. Pasal 72. Berdasarkan rumusan pasal 112 jo Pasal 72, maka dapat disimpulkan bahwa unsur utama (bestand delen) dari 
tindak pidana tersebut adalah: (1) dengan sengaja, (2) tidak melakukan pengawasan terhadap ketaatan penanggungjawab usaha dan/atau kegiatan atas peraturan perundangan dan izin lingkungan, dan (3) mengakibatkan terjadinya pencemaran dan/atau perusakan lingkungan sehingga menyebabkan hilangnya nyawa manusia.

Selanjutnya bentuk pengawasan kedua, yaitu pengawasan terhadap ketaatan penanggungjawab usaha dan/atau kegiatan atas ketentuan dalam peraturan perundang-undangan di bidang lingkungan. Larangan terhadap pengabaian terhadap pengawasan jenis ini diatur dalam Pasal 112 jo. Pasal 71. Berdasarkan rumusan pasal 112 jo. Pasal 71, maka dapat disimpulkan bahwa unsur utama (bestand delen) dari tindak pidana tersebut adalah: (1) dengan sengaja, (2) tidak melakukan pengawasan terhadap ketaatan penanggungjawab usaha dan/atau kegiatan atas ketentuan peraturan perundangan di bidang perlindungan dan pengelolaan lingkungan, dan (3) mengakibatkan terjadinya pencemaran dan/atau perusakan lingkungan sehingga menyebabkan hilangnya nyawa manusia.

Secara taksonomis, perumusan delik sebagaimana dinyatakan dalam Pasal 112, dapat dikualifikasikan sebagai delicten met materieele omschrijving, yaitu perumusan delik secara materiel (Wirjono Prodjodikoro, 1989:35). Dan delik yang dirumuskan dengan cara demikian disebut sebagai delik materiel (materieele delicten), yaitu delik yang perumusannya dititikberatkan pada akibat yang tidak dikehendaki (dilarang). Delik ini baru dianggap selesai apabila akibat yang tidak dikehendaki itu telah terjadi. Kalau belum, maka paling banyak hanya termasuk sebagai percobaan (Sudarto, 1990:57).

Memperhatikan kriteria delik sebagaimana dimaksud Pasal 112 adalah sebagai delik materiel, maka hal tersebut menimbulkan konsekuensi yang rumit menyangkut pembuktian (Sudarto, 1990: 66). Hal ini terkait dengan yang telah dikemukakan sebelumnya, bahwa salah satu unsur tindak pidana dalam pasal 112 adalah adanya akibat, yang berupa: pencemaran dan/atau perusakan lingkungan yang menyebabkan matinya orang. Artinya, penuntut harus mampu membuktikan hubungan kausalitas bahwa akibat tersebut disebabkan oleh tidak dilakukannya pengawasan terhadap ketaatan penanggungjawab usaha dan/atau kegiatan atas ketentuan peraturan perundang-undangan yang berlaku. Tidak terbuktinya hubungan kausalitas antara perbuatan yang melalaikan kewajiban hukum sebagai sebab dan akibat yang berupa timbulnya pencemaran dan/atau kerusakan lingkungan yang menyebabkan matinya orang berimplikasi terhadap tidak terbuktinya tindak pidana yang didakwakan.

b. Subyek yang Dapat Dipertanggungjawabkan

Memperhatikan bunyi Pasal 111 dan Pasal 112, maka kelihatan sekali bahwa adressat norma dari pasal tersebut adalah ditujukan secara khusus kepada pejabat yang berwenang mengeluarkan izin (baik izin lingkungan maupun izin usaha dan/atau kegiatan) serta melakukan pengawasan terhadap ketaatan atas persyaratan perizinan maupun peraturan perundangundangan.

Adapun pejabat yang diberikan wewenang untuk itu, secara atributif Pasal 37 ayat (1), Pasal 71 ayat (1) maupun Pasal 72 memberikan kewenangan kepada Menteri, Gubernur, atau Bupati/Walikota. Ini berarti, bahwa yang harus bertanggungjawab secara pidana terhadap setiap bentuk pelanggaran atau penyimpangan yang bersifat mal-administratif dalam kaitannya dengan penerbitan izin serta pengawasan terhadap ketaatan atas persyaratan izin dan peraturan perundangan adalah Menteri, Gubernur, atau Bupati/Walikota sesuai dengan porsi dan lingkup kewenangan masing-masing.

Prinsip pertanggungjawaban secara pidana sebagaimana yang dinyatakan di atas tidak berlaku, dalam hal pejabat itu mendelegasikan kewenangannya dalam hal pengawasan kepada aparat atau pejabat teknis di bidang perlindungan dan pengelolaan lingkungan. Hal ini dimungkinkan sebagaimana yang dinyatakan dalam Pasal 71 ayat (2).

c. Pertanggungjawaban Pidana

Pembicaraan tentang pertanggungjawaban pidana, tidak dapat dilepaskan dari pembahasan tentang tindak pidana. Demikian pula sebaliknya, tidak akan terjadi pemidanaan terhadap pelaku tindak pidana, kalau aspek pertanggungjawaban pidana pelaku tidak terpenuhi. Artinya dalam rangka pemidanaan konsep tindak pidana dan konsep pertanggungjawaban pidana adalah dua anasir yang terpisah (dualism) (Sudarto, 1990:40-50), ibarat dua sisi dari satu mata uang, terpisah, tetapi bersifat komplementer.

Seseorang tidaklah cukup alasan untuk dipidana apabila orang itu telah melakukan perbuatan yang bertentangan dengan hukum atau bersifat melawan hukum. Jadi meskipun perbuatannya telah memenuhi rumusan delik dalam undangundang dan tidak dibenarkan (an objective breach of a penal provision), namun hal tersebut belum memenuhi syarat untuk adanya penjatuhan pidana. Untuk penjatuhan pidana masih diperlukan adanya syarat bahwa orang yang melakukan perbuatan itu 
mempunyai kesalahan atau bersalah (subjective guilt). Dengan perkataan lain, orang tersebut harus dapat dipertanggungjawabkan atas perbuatannya, atau jika dilihat dari sudut perbuatannya, perbuatannya harus dapat dipertanggungkan kepada orang tersebut (Sudarto, 1990:85). Dalam konteks inilah berlaku adegium tiada pidana tanpa kesalahan (Keine Strafe ohne Schuld atau Geen Straf Zonder Schuld atau Nulla Poena Sine Culpa), yang juga disebut ajaran culpabilitas.

Secara konsepsional, kesalahan mengandung beberapa unsur (Sudarto, 1990:91-92) yaitu: a. adanya kemampuan bertanggungjawab dalam diri si pembuat (schuldfahigkeit), artinya keadaan jiwa si pembuat harus normal, $b$. adanya hubungan batin antara si pembuat dengan perbuatan yang dilakukannya (baik yang berupa kesengajaan atau kealpaan), dan c. tidak adanya alasan penghapus kesalahan, atau alasan pemaaf. Dalam hal ketiga unsur tersebut terpenuhi, maka orang yang bersangkutan bisa dinyatakan bersalah atau mempunyai pertanggungjawaban pidana, sehingga bisa dijatuhi pidana.

Pengertian dan pemahaman tentang pertanggungjawaban pidana sebagaimana tersebut di atas jika dipergunakan dalam memotret perumusan unsur kesalahan yang dilukiskan dalam Pasal 111 dan pasal 112 dapat dikemukakan sebagai berikut: (1) bahwa Pasal 111 tidak merumuskan secara ekplisit (tegas/tertulis) unsur kesalahannya (kesengajaan atau kealpaan), sehingga secara teoritis menimbulkan konsekuensi teknis yuridis dalam proses pembuktian di pengadilan, maksudnya Penuntut Umum tidak mempunyai keharusan untuk membuktikan unsur kesalahan pelaku (bersifat fakultatif); dan (2) sebaliknya Pasal 112 merumuskan unsur kesalahan secara tegas, terbaca (eksplisit), yaitu dengan katakata "... dengan sengaja".

Perumusan unsur kesalahan dalam bentuk kesengajaan tersebut menunjukkan dianutnya prinsip liability based on fault (pertanggungjawaban berdasarkan kesalahan atau asas culpabilitas). Bertolak dari asas culpabilitas ini, maka dalam pertanggungjawabannya tidak dapat diberlakukan "tanggungjawab seketika (strick responsibility)". Artinya secara teknis yuridis, Penuntut Umum mempunyai kewajiban untuk dapat membuktikan unsur kesalahan pelaku di dalam proses pemeriksaan di Pegadilan, sebab dalam hal ini unsur kesengajaan sebagaimana dimaksud merupakan unsur utama delik (bestand deel). Tidak terbuktinya unsur ini bisa mengakibatkan tidak dapat dipersalahkannya pelaku.

\section{d. Sanksi Pidana}

Berdasarkan perumusan sanksi pidana yang diatur dalam Pasal 111 dan Pasal 112, maka dikemukakan sebagai berikut: pertama, bahwa ditinjau dari jenis sanksi pidana (strafsoort), Pasal 111 merumuskan adanya 2 (dua) macam sanksi pidana, yaitu pidana penjara dan pidana denda. Namun demikian kalau dicermati secara seksama, bahwa kedua jenis sanksi tersebut dirumuskan dengan kata-kata “... dengan pidana penjara ... dan pidana denda ....", hal ini menunjukkan bahwa sesunguhnya hanya ada satu sanksi yang ditawarkan kepada hakim yaitu pidana penjara dan pidana denda secara bersamaan (komulatif). Berbeda dengan yang dianut dalam Pasal 112, yang merumuskan sanksinya dengan kata-kata "... dengan pidana penjara atau pidana denda ....", hal ini menunjukkan bahwa undang-undang memberikan kebebasan bagi Hakim untuk memilih salah satu dari 2 (dua) macam sanksi yang ditawarkan oleh undang-undang, yaitu pidana penjara atau pidana denda (alternative).

Kedua, jika dilihat dari segi berat-ringannya sanksi pidana (strafmaat), rumusan Pasal 111 maupun Pasal 112 dapat diketahui, bahwa kedua pasal menganut perumusan sanksi pidana maksimal, artinya hakim diberikan kebebasan untuk menakar berat-ringannya pidana yang dapat dijatuhkan sesuai dengan kesalahan pelaku asalkan tidak melampaui batas maksimal yang telah ditetapkan oleh Pasal 111 maupun Pasal 112.

Ketiga, apabila dibandingkan antara sanksi pidana yang diatur dalam Pasal 111 dan Pasal 112, maka dapat diketahui bahwa sanksi pidana yang diancamkan dalam Pasal 111 jauh lebih berat dibandingkan dengan sanksi pidana dalam Pasal 112. Hal ini menimbulkan pertanyaan besar, mengapa demikian. Padahal kalau ditinjau dari segi beratnya tingkat pelanggaran dan rumitnya pembuktian di pengadilan, seharusnya (secara ius constituandum) sanksi yang ada dalam Pasal 112 lebih berat dibandingkan dengan sanksi yang ada dalam pasal 111 .

\section{PENUTUP}

\section{Kesimpulan}

a. Perubahan terhadap Undang-Undang Pengelolaan Lingkungan Hidup (UUPLH) yang sekarang menjadi Undang-Undang Perlindungan dan Pengelolaan Lingkungan Hidup (UUPPLH) merupakan langkah responsif terhadap himbauan Resolusi No. A/CONF.144/L.4 tanggal 3 September 1990 untuk lebih mengefektifkan berbagai instrument hukum dalam rangka penanggulangan masalah lingkungan secara lebih progresif. 
b. Salah satu instrument yuridis yang dipergunakan dalam upaya penanggulangan masalah lingkungan tersebut adalah melalui kriminalisasi terhadap tindakan pejabat yang bersifat mal-administrasi.

c. UUPPLH mengatur adanya 4 (empat) macam tindakan mal-administrasi yang berimplikasi terhadap pertanggungan jawab pidana pejabat, yaitu: pertama, pelanggaran terhadap prosedur penerbitan izin lingkungan sebagaimana dimaksud Pasal 37 ayat (1); kedua, pelanggaran terhadap prosedur penerbitan izin usaha dan/atau kegiatan, sebagaimana diatur Pasal 40 ayat (1); ketiga, pelanggaran yang berupa pengabaian terhadap kewajiban hukum untuk melakukan pengawasan terhadap ketaatan penanggungjawab usaha dan/ atau kegiatan terhadap persyaratan izin usaha dan/ kegiatannya, sebagaimana dimaksud dalam Pasal 71 ayat (1); dan keempat, pelanggaran yang berupa pengabaian terhadap kewajiban hukum untuk melakukan pengawasan terhadap ketaatan penanggungjawab usaha dan/atau kegiatan terhadap persyaratan izin lingkungannya, sebagaimana dimaksud dalam Pasal 72 ayat (1).

d. Pertanggungan jawab pejabat atas keempat bentuk pelanggaran tersebut dapat dipersalahkan melanggar Pasal 111 dan Pasal 112 UUPPLH.

e. Dirumuskannya Pasal 112 sebagai delik materiel berimplikasi terhadap rumitnya pembuktian dalam proses pemeriksaan di pengadilan, sebaliknya Pasal 111 yang diformulasikan dalam bentuk delik formiel akan mempermudah bagi penuntut umum dalam pembuktian di pengadilan; namun sayangnya dilihat dari segi berat-ringannya sanksi pidana (strafmaat), kondisinya justru berbanding terbalik. Sanksi Pidana dalam pasal 111 jauh lebih berat dibandingkan dengan pasal 112 .

\section{Rekomendasi}

Berdasarkan analisa terhadap UUPPLH dapat diketahui bahwa undang-undang tersebut sangat akomodatif terhadap Hasil Konggres PBB ke-8 Tahun 1990 di Havana Cuba, sekaligus aspiratif terhadap desakan berbagai kelompok masyarakat yang menjadi korban atas penyalahgunaan wewenang pejabat publik di bidang penerbitan izin yang berujung dengan pencemaran dan/atau perusakan lingkungan.

Aspek akuntabilitas terhadap segala macam bentuk penyalahgunaan kewenangan dalam penerbitan izin di bidang lingkungan seharusnya menjadi barometer dalam penegakan hukumnya. Progresifnya UUPPLH mesti diimbangi dengan kuatnya penegakan hukum terhadap setiap bentuk pelanggaran.

\section{DAFTAR PUSTAKA}

Djatmiati, Tatiek Sri, 2007, Perizinan sebagai Instrumen Yuridis dalam Pelayanan Publik, Pidato Pengukuhan Guru Besar dalam Bidang Hukum Administrasi, Fakultas Hukum Universitas Airlangga, Surabaya.

Hadjon, Philipus M., et.al, 2011, Hukum Administrasi dan Tindak Pidana Korupsi, Yogyakarta: Gadjah Mada University Press.

Hamzah, Andi, 1994, Asas-Asas Hukum Pidana, Bandung: Rineka Cipta.

Huda, Chairul, 2008, Dari Tiada Pidana Tanpa Kesalahan Menuju Kepada Tiada Pertanggungjawaban Pidana Tanpa Kesalahan, Jakarta: Kencana Prenada Group.

Muladi, 1992, Teori-Teori dan Kebijakan Pidana, Bandung: Alumni. Alumni.

Muladi, dan Barda Nawawi Arief, 2010, Bunga Rampai Hukum Pidana, Bandung: Alumni.

Prodjodikoro, Wirjono, 1989, Asas-Asas Hukum Pidana di Indonesia, Bandung: Eresco.

Rangkuti, Siti Sundari, 2000, Hukum Lingkungan dan Kebijaksanaan Lingkungan Nasional, Surabaya: Airlangga University Press.

Schaffimeister, et al., edit. J.E. Sahetapy, 2011, Hukum Pidana, Bandung: Citra Adtya Bakti.

Sudarto, 1990, Hukum Pidana I Cetakan ke II, Yayasan Sudarto, Semarang: Fakultas Hukum Universitas Diponegoro. 